\title{
Memories of humiliation, cultures of resentment towards Edom and the formation of ancient Jewish national identity
}

\author{
JUAN MANUEL TEBES \\ IMHICIHU-CONICET, Catholic University of Argentina, University of \\ Buenos Aires, Buenos Aires, Argentina
}

\begin{abstract}
While the impact of wars and national humiliations in the ancient Jewish cultural nationalism has been studied extensively, little has been written about the role of the related phenomena of cultures of resentment against foreigners or minority groups. Well before the Hellenistic period, the Jewish tradition had already created its own perfect enemy whose very name became synonymous of Israel's most malicious antagonist: Edom. This article aims to study the changing attitudes towards the Edomites/Idumaeans from the late Judaean kingdom to the Roman period using a long-durée perspective, particularly the growth of memories of humiliation and feelings of resentment product of the alleged crimes of Edom during Judah's fall and exile.
\end{abstract}

KEYWORDS: Ancient nationalism, Cultural memory, Edom/Idumaea, Judaism, Scapegoating

\section{Introduction}

The moment of the emergence of the ancient Jewish national identity in Palestine is disputed among scholars. ${ }^{1}$ There is nevertheless consensus that by the Hellenistic period the identity of the local Judaean population had at its core a few easily discernible central concepts: (1) a trans-clan, trans-tribal collectivity united by genealogical bonds, with a common descent, (2) a delimited trans-local territory, (3) the authority of religious - temple, priesthood - or secular - kingship, army - elites, (4) a God-given law that should be obeyed in the land, and (5) a common religion, language, and sacred text (Aberbach 2008: 28; Goodblatt 2006; Grosby 2002: 22-7; Mendels 1997). These notions were greatly strengthened during periods of military conflicts, stimulating the collective pride in moments of territorial expansionism or helping to swallow the bitter pill in times of national humiliation. The struggles against the Seleucid domination and non-Jewish neighbours and the successive rebellions against Rome provided fuel for the emergence of a literature that 
extolled the liberation fighters against the cruel foreign adversary aiming to destroy the Jewish religion alongside their cultic institutions and customs, while at the same time condemning the corrupt, Hellenized elites (Aberbach 2000; Mendels 1997: 24-6, 124-6; Smith 2002: 56-7; Schwartz 2009: 33-6).

Although traditions of national enmity and cultures of resentment are traditionally related to the rise of modern nationalism in 19th century Europe, scholars endorsing a 'perennialist' perspective have argued they were already present in premodern times, even in antiquity (e.g. Grosby 2003; Roshwald 2006; Smith 2003). Wars, and particularly major military defeats, constituted major incentives for bursts of cultural nationalism and intellectual creativity and of feelings of humiliation and resentment, xenophobia, 'lost cause' legends, 'divine punishment' themes, and 'stab-in-the-back' myths (Harkavy 2000; Schivelbusch 2003). Collective resentment typically stems from memories of military defeat, national humiliation, and social oppression. It has been historically used as a potent instrument for expressing demands of national regeneration and sweeping socio-political changes. Well-known modern cases include the Reconstruction Era southern states, post-1870 France, and interwar Germany, but as we will see below cultures of resentment can cut across many decades and periods.

While the impact of wars and national humiliations in the ancient Jewish cultural nationalism has been studied extensively, little has been written about the role of the related phenomena of cultures of resentment against foreigners or minority groups. Well before the Hellenistic period, the Jewish tradition had already created its own perfect enemy whose very name became synonymous of Israel's most malicious antagonist: Edom. One of the most important questions that traverse the history of ancient Judaism is the relationship with the Edomite/Idumaean population, a foreign minority in Iron Age southern Judah and later the predominant population in Persian, Hellenistic, and Roman period Idumaea. Attitudes towards their special neighbours constituted an integral part of the formation of the Jewish identity, centrally crossing its variable notions of relationships with foreigners and affecting fundamental questions of the history of Judaism.

This article aims to study the changing attitudes towards the Edomites/Idumaeans from the late Judaean kingdom to the Roman period using a long-durée perspective, particularly the growth of memories of humiliation and feelings of resentment product of the alleged crimes of Edom during Judah's fall and exile. The textual evidence will be critically analysed against the epigraphic and archaeological record showing the development of the identitary experience of the population that lived in Idumaea and the northern Negev and comparing the material culture that developed and changed in these areas from an interdisciplinary perspective. Efforts will be focused on the historical context of the culture of resentment towards Edom, the fluid cultural boundaries between the Judaean and Idumaean populations, the religious eclecticism in the late Hellenistic period, and the transition from 'Edomite', to 'Idumaean', to 'Jewish Idumaean' identity. This case study will 
contribute in a unique way to significant historical questions about the origins of the Jewish identity and to the much wider debate of the relationship between memories of humiliation and the development of national identities in ancient societies.

\section{Cultures of resentment and national identities in ancient times}

Cultures of resentment towards foreigners or minority groups provide a powerful incentive for the development of national ideas, in modern and ancient times. The rise of modern nationalism in 19th century Europe usually - but not always - had as a main constituent theme the liberation struggle against the foreign enemy occupying part or the totality of the national territory (e.g. the Greek, Slavic, Polish, and Italian nationalist movements) (Hobsbawm 1996: 139-42). Given certain conditions, traditions of national enmity can develop throughout decades, or decline and revive much later, being often conflated with strong cultural, ethnic, religious, and class emotions. A love-hate attitude towards the motherland Spain was vital during the Latin-American wars of independence and played a significant role in the independent period as the creole elites desperately worked to detach themselves from their colonial heritage. Spain's role was later superseded by Great Britain and the United States, two superpowers about which Latin-Americans equally have two-sided attitudes, being enormously attracted to their cultures but at the same time resenting their political power and economic prosperity (Snyder 2003: 227-48).

The role of enmity in the development of national ideas in the ancient world, even if less clear, was also prominent. Although the idea of nation was present in ancient Athens (Cohen 2000; Roshwald 2006: 22-30) and took definitive force during the Persian Wars, it never transcended the city-state particularisms, so there was never a true Greek national identity (Grosby 2002: 32; Hornblower and Spawforth 1998: 488-9; Kohn 1961: 52-3; Motyl 2001: 200). It is during the Punic Wars, however, when we have the clearest evidence of prolonged resentment between both sides in war. Although no actual Carthaginian account survives, Polybius' story of the oath taken by a young Hannibal 'never to be friend with the Romans' reflects, to a great extent, the bitterness felt by Carthage's elites over the outcome of the First Punic War, resentment that was going to lead later to a second conflagration (Hoyos 1997: 152-3). More clearly, the war efforts of the Roman Republic served as catalyst to amalgamate the different internal factions (Barash and Webel 2013: 177) and after victory contributed to the forging of an ideology of divine favour for the national cause and its leaders, through the display of the war spoils and the commission of statues, columns, and paintings (Gruen 1992: 88-90). Later patriotic narrative, such as Sallust's and Livy's writings, tried to reconnect the Romans with their glorious past: the wars 
against Cartage served above all as a validation of the Roman national pride and its collective virtus (Chlup 2012: 210-4).

Cultural antagonisms between ancient superpowers were also present in the ancient Near East, and while it is true that our relevant sources were almost always produced by state and temple institutions, they also present similar complex and multilayered views of the external other. The best known case is the long rivalry between Assyria and Babylon. Babylon was considered to be, at least since the times of Hammurabi, the cultural and religious centre of Mesopotamia, having inherited the role of older Sumerian cities. It soon began clashing with its emergent northern neighbour Assyria that acquired status of upper-level kingdom in the 14th-13th centuries BCE and whose kings aspired, following a long-held tradition in expansive Near Eastern kingdoms, to be universal sovereigns (Radner 2014: 102). The Neo-Assyrian period thus saw the construction of a strong Assyrian national identity (Bedford 2009: 59-61; Limet 2005: 377-8, 381-3; Liverani 1992; Mann 1986: 235-6: 1033; Pongratz-Leisten 2001: 224-30; Porter 1993: 126). Simo Parpola (2004) has extensively studied how the Assyrian royal elites, facing the difficult task of ruling over a vast multiethnic empire, created the concept of an Assyrian national identity to unify the diverse peoples under their hegemony into a single corpus. Central to this goal was a conscious and very successful policy of assimilation and integration of the conquered peoples into one Assyrian identity, unified under one semi-divine king, worshipping the national gods, and speaking a common language. The Assyrian kingship's claim of universal aspirations naturally collided with the traditional cultural supremacy of Babylon, and the centuries-long political and cultural clash between the two peoples provided more impetus to the development of both national identities.

Despite the brutal history of violence between both peoples, the Babylonian culture always exerted a strong attraction to the Assyrians, who were fascinated by their ancient religion, scholarship, literature, and astronomy (Brinkman 2006: 16-7; Frame 2007: 250-1). Since the 730s BCE, most of Babylon was de facto territory of Assyria and, although enjoying varying degrees of autonomy, it revolted several times with disastrous consequences. While Assyrian kings twice sacked (Tukulti-Ninurta I, 1235-1199 BCE) or destroyed (Sennacherib, 705-681 BCE) Babylon, much effort was spent in symbolically establishing the superiority of the Assyrian culture. Thus, Tukulti-Ninurta I removed the statue of Marduk, Babylon's chief deity, and celebrated the Akitu (New Year) festival in his honour in Assyria, proclaiming the pre-eminence of the national god Ashur and taking rich scholarly texts to Assyria. Similarly, Sennacherib aimed at transforming Assyria into a 'New Babylon', removing again Marduk's statue and Babylon's ashes to Assyria, celebrating the Akitu festival at home and exalting Ashur at the expense of Marduk in religious and literary texts (Brinkman 2006: 38-43; Frame 2007: 52-9; Na'aman 2010: 6-14). The nature of the extant textual evidence makes almost impossible to know if this cultural struggle extended beyond the ruling classes, but what is certain is that 'Babylonia was for these elites not simply a 
political or military problem of governance ... what was ultimately at stake was the neutralization of the cultural/cosmic imperium that Babylon represented and its transfer to Assyria' (Machinist 2006: 296). Ultimately, Sennacherib's strong anti-Babylonian stance was short-lived because his son Esarhaddon rapidly reversed most of his draconian measures, restoring Babylon as a political and commercial centre, rebuilding its temples and walls, returning the statues of Babylonian gods, and even openly praising Marduk. The reasons behind Babylon's downfall were conveniently forgotten and his father's responsibility deliberately omitted (Brinkman 2006: 40-3; Frame 2007: 67-78; Porter 1993: 41-66).

This did not deter the Babylonians to look getting rid of the Assyrian domination, which after several attempts Nabopalassar succeeded in 614-2 BCE with the conquest and sacking of Assur and Nineveh. After a last stand in the western provinces, the Assyrian empire fell not to be re-established again. The Babylonian empire rested on a similar strong nationalistic ideology, focused on the king and the central role of the city of Babylon as a god-built metropolis and cosmic centre with a perpetual destiny. An important element was the liberation theology that consciously capitalized on the expulsion of Assyria, the wicked and culturally inferior enemy that had dominated Babylon for so long (Frame 2007: 258-9, 261; Sheriffs 1988: 20-38).

This short outline of the complex history of cultural relationships between Assyria and Babylon demonstrates that traditions of national enmity and related feelings of cultural inferiority/superiority provided fuel for the development of national ideologies in the ancient Near East. To be sure, these are cases of extensive multiethnic empires that, like the Roman Empire centuries later, struggled for regional hegemony and developed ideologies serving to amalgamate their diverse constituting parts. But a similar case can be made of smaller cultural identities in ancient times, such as the long-lasting Judaean cultures of resentment towards Edom.

\section{Edomites in Judah and the 'brotherhood' of Esau folklore}

Although Edom as a geographical name is already known from Egyptian sources dating as early as the 13th century BCE, the earliest textual attestations of an Edomite polity in southern Transjordan date to the early 8th century BCE. ${ }^{2}$ Archaeological excavations have revealed the emergence of a complex society in the central plateau southeast of the Dead Sea, known by biblical and Assyrian sources as the kingdom of Edom (Figure 1). The flourit of this polity occurred during the 7th and first half of the 6th centuries BCE, when several local chiefs claimed the title of 'kings' of Edom, even if their sovereignty only extended to the hinterland of the administrative centre of Buseirah (Tebes 2013: 49-51, 121-35). West of the Edomite highlands extended the arid valleys of the northern Negev, a territory nominally under 


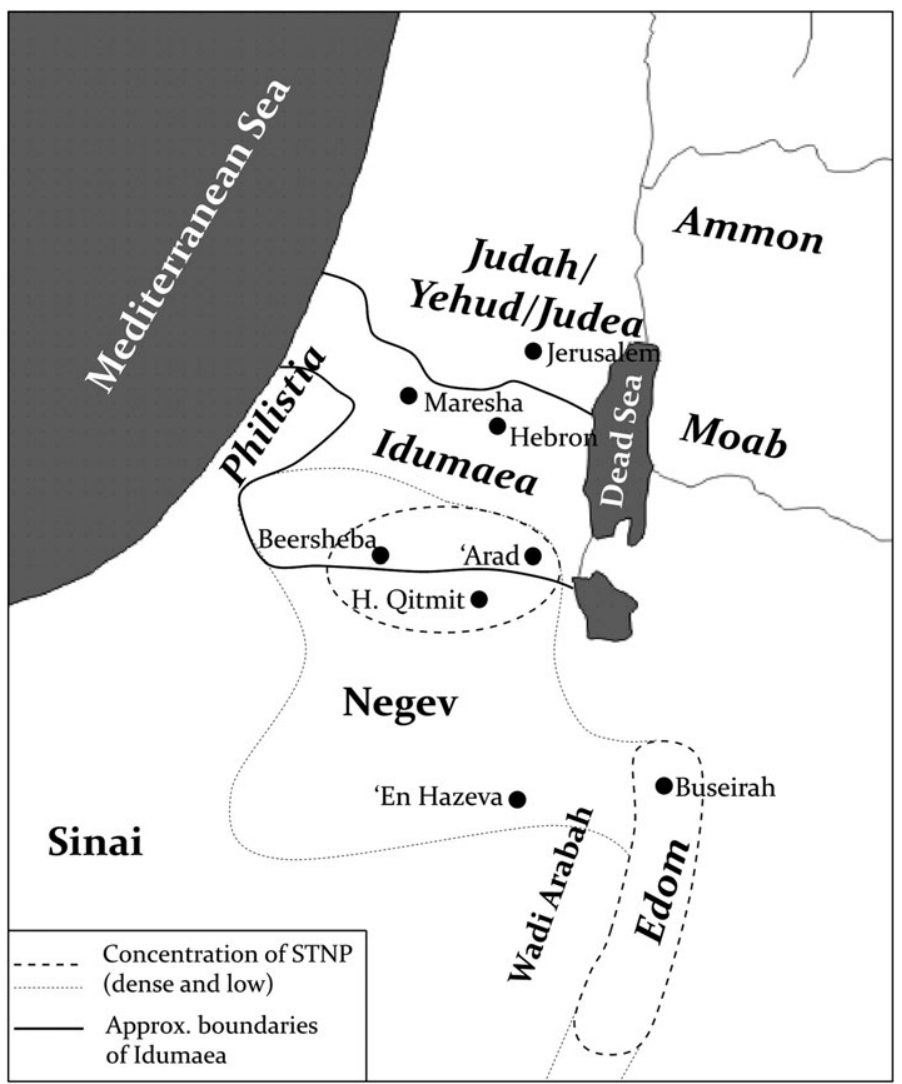

Figure 1. Edom and Idumaea from the Iron Age to the Roman period. STNP = Southern Transjordan-Negev Pottery.

the control of the kingdom of Judah but de facto a no man's land where nomadic groups and villagers of diverse origins moved and interacted. The Judaeans established fortified villages and forts along the most important routes, clashing repeatedly with the Edomites over the control of the area (Bartlett 1989: 115-45).

Among the diverse peoples settled and moving throughout the Negev were undoubtedly Edomite groups of local or Transjordanian stock, as attested by the appearance of locally manufactured decorated wares similar to those found at Buseirah and cooking-pots made in southern Transjordan and transported to the Negev, known with the misnomer of 'Edomite pottery' ${ }^{3}$ and found alongside Judaean vessels. Other similar material culture included 'Edomite' open-air cultic shrines located close to Judaean settled centres (Horvat Qitmit and 'En Hazeva), and epigraphic sources naming Qos, the national god of the Edomites (Tebes 2011a). While the process behind the appearance of these cultural traits is still debated - they are probably the result of multiple 
socioeconomic factors, such as nomadic movements between the Negev and Edom, trade with the Edomite plateau, and settlement of Edomites in Judaean villages -, the evidence seems to point to mostly peaceful coexistence between the Judaean community and the Edomite groups. Hebrew ostraca found at 'Arad in the northern Negev referring to the 'evil' done by Edom (1. 40) and to the dispatch of reinforcements 'lest Edom should come there' (1. 24), long adduced as clear signs of military pressure from Edom, have convincingly been reinterpreted as conflicts over grazing rights, probably in the Neo-Babylonian period (Guillaume 2013).

It is within this multicultural milieu that emerged the oral folklore that linked Judaeans and Edomites through fictive kinship relationships, as reflected by family stories that later found their way into the Bible. The Judaeans, following a long-held tradition common to other ancient Near Eastern societies, expressed the geographical and political realities of their time through the language of kinship. Close social and economic contacts between Judaean and Edomite clans in the Negev during the 7th to early 6th centuries $\mathrm{BCE}$ (neighbourhood, joint economic ventures, and intermarriages) were retroactively situated in the time of the patriarchs (Tebes 2013: 137-51). Thus, Jacob and Esau, eponymous ancestors of Israelites and Edomites, respectively, became twin brothers through their birth from Isaac's wife Rebekah, living a conflictive yet mostly peaceful life. The biblical narrative portrays Jacob as a clever character that twice deceives his credulous brother, obtaining his birthright and Isaac's blessing by cunning, but at last Esau did not guard any resentment to Jacob (Gen. 25:19-34; 27; 32:4-32; 33:1-17). The tales, as we have them, must be a composite. These stories seem to presuppose the existence of the kingdoms of Judah and Edom and their troublesome history, while the several statements referring to the two nations ('one nation shall have the mastery of the other, and the elder shall serve the younger'; Gen. 25:23b; 'be master of your brothers; may the sons of your mother bow down before you!'; Gen. 27:29a) are probably later rationalizations legitimizing the political ascendancy of the earlier over the latter.

This state of affairs, which left few if any traces of negative attitudes towards the Edomites in the Hebrew Bible, lasted until the delicate balance of power in the southern Levant was broken by the Babylonian military interventions in the 590-50s. The destruction of the local political systems brought much misfortune to the Judaeans, while the ensuing political vacuum did not but promoted the emergence of scapegoat ideas of which the Edomites were going to be the main target.

\section{Memories of humiliation and scapegoat notions after Judah's collapse}

The political consolidation and religious centralization that Judah experimented in the late 7 th to early 6 th centuries BCE came to a sudden halt with the military expansion of the Neo-Babylonian Empire in the southern 
Levant. In $586 \mathrm{BCE}$, the city of Jerusalem was taken and sacked by Nebuchadnezzar's army; the temple of Yahweh and the palace were destroyed, and the royal and priestly elite exiled along with large parts of the population. Most defeated peoples known from ancient times were decimated; their political entity destroyed, and their culture assimilated. The case of the Judaean people constituted a notable exception, but the annihilation of their kingdom and the experience of exile that ensued ushered equivalent deep feelings of humiliation. The ideological response among the exiled Judaean upper classes was multifaceted and varied with time, but two main rationalizations of defeat emerged. The earliest reaction was the development of a theory of divine retribution, common among ancient Near Eastern societies, that explained the military defeat as God's punishment for his people's sins (Aberbach 2005: 224, 227-8). The earliest accounts of the fall of Jerusalem (2 Kgs. 24:18-25:8-21; Jer. 39:1-10; 52:4-23) put the blame on the sins of Zedekiah, Judah's last king, wicked actions which brought about Yahweh's rage. According to this view, the Babylonians and their king Nebuchadnezzar were no more than the earthly agents of the divine castigation, such as Yahweh had used the Assyrians to castigate the sins of the northern kingdom of Israel barely once century earlier.

A second rationalization of defeat emerged after the Persians replaced the Babylonians as the main power in the Near East, authorizing part of the Judaean exiles to return to Jerusalem and recommence the cult of Yahweh. Contrary to their expectations, the erstwhile territory of Judah was greatly reduced to a small province (Yehud) in the hilly country surrounding Jerusalem. Worst of all, this land was not empty, but was settled by the people that had remained living alongside foreign groups, most particularly Edomites residing predominantly in the northern Negev but migrating slowly to the north. It is possible that the phenomenon of 'Edomitization' accelerated in the political vacuum caused by the falling down of the Judaean state apparatus in the Negev and its substitution by the more relaxed Persian administration (Blenkinsopp 2000), a process that could not have passed unnoticed to the southern Transjordanian Edomites, which both archaeological and epigraphical evidences attest continued enjoying political independence at least three decades after the fall of Judah. ${ }^{4}$

The growing number of Edomites in Cisjordan provided fertile ground for the notion that their presence was a result of their mischievous behaviour during Judah's most stressful times. Several biblical prophetic and poetic texts written during the Persian period openly accuse the Edomites of treacherous behaviour during the fall of the Judaean monarchy and the destruction of Jerusalem, either as direct agents of destruction or as joyful witnesses. Most of these texts make use of very general graphic language with a vivid lack of historical details (Bartlett 1989: 151-5; Becking 2016; Dicou 1994; Glazier-McDonald 1995; Tebes 2011b: 228-30). The book of Obadiah, work almost entirely devoted to the Edomite 'question', goes to great lengths to blame Edom, accused of being as bad as the Babylonians, of having done 
violence to his brother and feasting on his misfortune, and of looting his possessions and assassinating fugitives (vv. 11-14). Psalm 137:7 intensely recalls the Edomites' despicable conduct: 'Remember, Yahweh, to the Edomites' cost, the day of Jerusalem, how they said, Down with it! Raze it to the ground! The theme of the perfidious attack on his brother reappears in a late interpolation made to the pre-exilic book of Amos: 'because he has pursued his brother with the sword, because he has stifled any sense of pity, and perpetually nursed his anger and constantly cherished his anger (1:11).

The imagery of violence, swords, and blood is even starker in Joel, which openly accuse Edom of 'the violence done to the children of Judah whose innocent blood they shed in their country' (4:19), and Ezekiel, which refers to the 'great crimes' committed by Edom (25:12), principally of having 'betrayed the Israelites to the sword in the day of their distress' (35:5). Similar jarring motives can be found in Lamentations (4:21-2) and Isaiah (34:5-13).

Traditional text-based analyses - particularly based on the scapegoat notions present in the recently cited biblical texts - place much emphasis on the feelings of hatred and revanchism towards Edom as a central factor in strengthening the development of the ancient Judaean identity. Despite the mostly harsh anti-Edomite language that survived in the biblical narrative from the Persian period, the contemporary epigraphic and archaeological evidences paint a more nuanced picture.

\section{From Edomites to Idumaeans and Jewish polemics}

As we have seen, from the 7th century BCE on the identity of the population living in the northern Negev began to experience long-term transformations that accelerated during the Persian and early Hellenistic periods. Epigraphic traits of the Edomites start to be concentrated on the northern Negev and territories as north as Hebron, while the name Edom totally disappears as a reference to the southern Transjordanian entity. Other groups also migrated to this area, particularly Arab nomadic tribes now controlling the Negev routes of the caravan trade (Eph'al 1982: 192-214; Graf 2015). There is some debate on when the term Idumaea began to be employed, whether in the Persian (Kloner 2015) or the early Hellenistic periods (Levin 2015), when the 'hyparchy' of Idumaea is firstly attested. What is clear is that the new name officialized the changes in the demographic balance that had occurred in the area during the previous centuries.

By the 4th century BCE, the epigraphic sources show a vibrant multiethnic community living in the northern Negev and Idumaea. Statistical analyses of the 1,300 personal names present in the hundreds of Aramaic ostraca discovered in this area reveal the coexistence of clan-based groups of diverse ethnic background - most specifically, 32 per cent Arabs, 27 per cent Idumaeans, 25 per cent Western Semitics, 10 per cent Judaeans, and 5 per cent 
Phoenicians, - with only a minority of persons maintaining their progenitors' ethnic onomastica (Stern 2007). In sum, ethnic boundaries were low, and identities were fluid.

The attitude of the Yehud's golah community towards their neighbours and the Judaean population that remained in the land after the Babylonian conquest was not monolithic, and vestiges of two main different positions can be found in the biblical writings (Fried 2007: 179-204; Kessler 2006: 107-12). Some texts reveal an inclusive approach towards the non-Judaean population, although this view was chiefly presented through historical fictions such as the book of Ruth (where a Moabite woman not only becomes a part of Israel but is described as the ancestor of king David), or in a subtly manner in genealogical lists like those present in I Chronicles.

The book of Chronicles, work written in the Persian period, exhibits genealogical lists linking Judaean and Edomite families or clans through the repetition of their eponyms' names. Standing prominently in these lists are names of members of Judaean and Simeonite clans that are paralleled in the names of the descendants of Esau and Seir (the putative predecessor of Esau in Edom) that appear in Gen. 36 (Knoppers 2001: 23-8; Tebes 2013: 144-5); for example, among the many names, Esau's grandson Kenaz (Gen. 36:11) can be linked to the Kenaz of the Judaean 'Calebite' clan listed by Chronicles (1 Chron. 4:15). It is very clear the intention of including at least some Edomite clans within the realm of the large Israelite family, thus echoing the picture given by the contemporary Idumaean Aramaic ostraca.

But for some members of the priestly circles, the only thing that counted was ethnic purity, and thus every effort was spent against intermarriages outside 'Israel', here narrowly defined as the community of the newly arrived exiles. This stance apparently had at first the upper hand, as can be seen from the harsh measures (divorce, exclusion, confiscation of property, corporal punishment, and expurgation) prescribed by the Yehud priesthood against exogamy and described in the books of Ezra and Nehemiah. Whether or not these reforms were carried out as described in the 5th century BCE, they do reflect a xenophobic stance characteristic of defeated societies. It is telling to note that, despite the scapegoat notions so popular in the biblical discourse, explicit biblical references to the situation of the Edomites in the Persian period are few and vague. Although allusions to the Edomites are notably absent in Ezra and Nehemiah, they do refer, however, to the Jews settled in 'Beersheba and its villages' (Neh. 11:26-30), that is, the northern Negev, and to Arabs living south of Yehud, portrayed as bitter enemies (Neh. 1:19; 4:1; 6:1).

Whether this reflects a deliberate attempt in Ezra and Nehemiah to remove the Edomite population from history is hard to tell, but closest analysis of these and other biblical texts of the same period may indicate conflicts and negotiations over the holding of cultic positions in the Jerusalem temple by personnel of Edomite origin. Some hints are provided by the presence in Chronicles' narrative of characters with Edomite or Edomitizing names portrayed as temple or cultic personnel living in king David's times and later. 
These characters - with names such as Obed Edom (repeated four times: 2 Sam. 6:10-2; 1 Chron. 13:13-4; 15:18, 21, 24-5; 16:5, 38; 26:1-19; 2 Chron. 25:24), Kushaiah (1 Chron. 15:17, cf. 1 Chron. 6:44; 2 Chron. 29:12), and Barkos (Ezra 2:53; Neh. 7:55) - may reflect the holding or claims of holding of cultic positions during the Persian period by people with Edomite background (Tebes 2011b: 243-5). These Edomites seem to have been clustered around temple personnel devoted to singing known as Ezrahites; they are mentioned with much detail by Chronicles as performing their duty already under David (e.g. 1 Chron. 25) and were arguably the authors of some Psalms (88; 89), but they are enumerated, notoriously unnamed, in Ezra (2:65b) (Amzallag 2015). The presence of Edomites in the temple of Jerusalem was a clear source of discord among the Judaean priestly circles of the Persian period that, although conveniently concealed in 'hidden polemics' (Amit 2003), represented real conflicts of power with an emerging foreign minority.

\section{Idumaean identities and the Jewish (re)telling of history}

In the Hellenistic and early Roman periods, the social and political entanglement of the Idumaeans and Judaeans reached levels previously unseen, with the role of Edom in the Jewish literature intensifying accordingly.

During the Maccabean revolt, much effort was spent in fighting against the neighbouring communities of Palestine and Transjordan, among them the Idumaeans (1 Mac. 4:29; 3:41; 5:3, 65). According to Flavius Josephus' account, the Hasmoneans forced the conversion to the Jewish practices to defeated peoples such as the Itureans in Galilee and especially the Idumaeans, but it is not clear if this was part of a general policy of Judaization. The turning point is traditionally believed to be John Hyrcanus' subjection and conversion of the Idumaeans in ca. 112/1 BCE. There is some debate whether this conversion was forced or voluntary; ancient sources can be cited for either position (Bryan 2002; Cohen 1999: 110-5; Kasher 1988: 46-62; Kokkinos 1998: 88-90). Josephus seems to point to a forced conversion, for the Idumaeans were permitted to stay 'if they would circumcise their genitals, and make use of the laws of the Jews', so that 'they were thereafter no other than Jews' (Ant. 13.257-8). Whether this meant physical circumcision for all the Idumaeans or, what seems more likely, a symbolic circumcision with little bearing on the daily life (Eckhardt 2012: 100-3), it was certainly an appealing choice for many Idumaean notables. The process of conversion was not straightforward, however, and some Idumaeans were adamant in maintaining their traditional customs. Josephus, again, provides us the case of Kostobaros, a governor of Idumaea that belonged to a family of priests of the Edomite deity Qos, who unsuccessfully conspired against Herod to restore the old traditional practices (Ant. 15.253-5) (cf. Marshak 2012: 125; Schwartz 2009: 51). Therefore, there is evidence to suggest that, while for some Idumaeans 
conversion to Judaism was intentional and even advantageous, for others it was totally compulsory and needed to be opposed.

Although the written sources depict the conversion of the Idumaeans as a rapid event, it was the end result of identitary changes that were occurring among the Idumaeans since at least the late Persian period. Recent archaeological discoveries in Maresha, a Hellenized town in western Idumaea with remains dating to the late Hellenistic and early Maccabean periods, paint a complex picture, where material remains clearly signalling an Idumaean identity, such as terracotta figurines of horse and camel riders (Erlich and Kloner 2008), consumption of pigs (Perry-Gal et al. 2015), and Qos theophoric names, coexisted with others of more mixed nature. The population of Maresha exhibited a mixture of 'Idumaean' and 'Jewish' cultural traits, such as purification installations similar to miqva ot, practice of circumcision as evidenced by circumcised phalli, holey vessels appearing to reflect Mishnaic rules, aniconic divine representations, and burials with bone collection (Kloner 2011; Stern 2012; Stern and Noam 2015). Idumaean marriage contracts were identical to the Jewish ketubbot and both used Aramaic as formulaic language (Eshel and Kloner 1996).

It is clear from the extant sources that the process of cultural assimilation, and later, political integration of the Idumaeans into the Jewish realm, far from alleviating the culture of resentment among Judaean circles, stimulated a harsh rhetoric of antagonism full of biblical imagery, one in which Edom played the role of the perpetual enemy. The Jewish literature describing the Maccabean revolt, above all 1 Maccabees, explicitly do so by using a biblical-charged language (Gruen 1998: 3, 8), such as the description of Judas Maccabeus' victorious war against 'the sons of Esau in Idumaea' (5:3; followed by Ant. 12.8.328). It is probable that this conflict left a mark in the book of Jubilees, a 2nd century BCE enlarged retelling of the history of the Jewish people from Creation to Moses. Jubilees expands considerably the story of Jacob (Israel) and Esau (Edom) with a tale that has no biblical prototype, extending the brotherly conflict to their descendants (Jub. 37-8). In it, Esau's sons reproach him for his subordination to Jacob, compelling him, after initial hesitation, to wage war against his brother and sons. Despite Jacob's invocation to the brotherly relations, Esau did not relinquish. In the ensuing battle, he was killed by an arrow, and his sons had no option but to make peace with Jacob. The composition of this story is likely contemporary to the Hasmonean campaigns against Idumaea, if not its ultimate conquest, as the closing sentence, 'and the sons of Edom have not got quit of the yoke of servitude which the twelve sons of Jacob had imposed on them until this day' (Jub. 38.14), was probably influenced by those events (cf. Mendels 1997: 45, 97, 183; VanderKam 2001: 77-8). Jewish expansionism in Idumaea is also likely behind a short reference in the contemporary Wisdom of Sirach to the inhabitants of Mount Seir' (an archaic term for the Idumaeans) as one of the nations 'that my soul detests' (50:25-6). Edom was also present in the Jewish apocalyptic literature alongside Ammon and Moab (War Scroll 1QM I.1; New Jerusalem 
4Q549 2.III.18) as one of the enemies of the 'Sons of Light' that will be defeated in the end of times. Similar negatives views of Edom and Esau resonate in contemporary Jewish works such as the Testament of the Twelve Patriarchs, 1 Enoch, and 4 Ezra, although some of the allusions are allegorical and of difficult interpretation (Feldman 1998: 322-3).

The old leitmotiv of the Edomite treachery during Judah's fall resurfaced in the apocryphal book of 1 Esdras, a reworked Greek version of Chronicles, Ezra, and Nehemiah, probably written between the 3rd and 1st centuries BCE (Talshir 1999). In a fictional story with no parallel in the canonical literature but heavily influenced by the Hellenistic court stories, the Jew Zerubbabel wins a contest and asks Persian king Darius to perform the vow that he had promised when he came to the throne: 'you promised to rebuild Jerusalem ... and you too made a vow to rebuild the temple which the Edomites (Idoumaioi) burnt when Judaea was ravaged by the Chaldeans' (4:45). The Persian king, needless to say, complied with these wishes, giving safe conduct and guaranteeing the liberties of the Jews returning to Judaea, and assuring that 'the Edomites (Idoumaioi) should surrender the villages they had seized from the Jews' (4:50) (Coggings and Knibb 1979: 32). While the tale is absolute fabrication, Hellenistic Jewish readers could get a great deal of delight from a story that reinterpreted the return to their homeland as the consummate act of a Jew outsmarting their Persian rivals, and at the same time taking delicious revenge against their perfect enemies at home.

\section{Jewish anti-Roman nationalism and Edom as allegorical figure}

Whether or not the conversion of Idumaeans was forced, aristocratic families of Idumaean stock fully integrated into the Hasmonean court as royal officials. The most notorious was the family of Herod, who after having overthrown the last Hasmonean king, ultimately was appointed as Roman client king of Judea (Marshak 2012; Ronen 1988). The long despotic rule of Herod (37-4 BCE) and his subservient status towards the Romans left a lasting impression in the Jewish memory, despite the building frenzy that characterized his kingdom that included the total renovation of the temple of Jerusalem (Kasher 1988: 126-72). The harsh, and in many levels incompetent, Roman rule in Judea that ensued either through direct rule or puppet-regimes, generated strong antiRoman nationalistic feelings that exploded in two disastrous Jewish revolts against Rome (66-70, 132-5 CE).

Paralleling the Judaean responses to Judah's fall centuries earlier, the misfortunes that befell the Judaean population during the 1st and 2nd centuries $\mathrm{CE}$ - the destruction of the Temple, the annihilation and exile of the local Jewish population, and the deprivation of their religious and ruling classes' political power - inspired a cultural renaissance defined in terms of religious culture. 'Jewish cultural nationalism, with Hebrew literature at its core, became vital to Jewish survival. It kept alive the possibility, however faint, 
of a political awakening' (Aberbach 2000: 357). And, echoing the reactions to the $586 \mathrm{BCE}$ catastrophe, central to this burst of nationalism was the culture of intolerance against the Idumaeans, shared by everyone but a few, and the allegorical symbolism that began to be attached to Edom.

Josephus' works are full of prejudice against the Idumaeans, and they surely echo similar feelings among the Jewish elite of the 1st century CE; 'for some Judaeans ... Idumaeans like Herod would always be outsiders, a combination of parvenus and country bumkins' (Cohen 1999: 18). Despite the political collusion of the Hasmonean and Herodian families, the latter's Idumaean origins were never forgotten; Josephus has Antigonus - the last Hasmonean king - saying that Herod 'was no more than a private man, and an Idumaean, i.e., a half-Jew' (Ant. 14.403) (see the remarks of Goodblatt 2006: 20; Eckhardt 2012).

The role of the Idumaeans in the Jewish-Roman wars was certainly far from apathetic, or at least that is what emerges from Josephus' account of the first revolt. The extent of the Idumaean embracement of the Jewish religion is demonstrated by their joining the Zealots in Jerusalem, although their conduct was seen as controversial. Josephus exhibits harsh stereotypes of the Idumaeans joining the Zealots, depicted as a people (ethnos) distinct from the Jews (Appelbaum 2009). Despite their involvement in the revolt, they are seen as bloodthirsty hooligans ('a turbulent and disorderly people [ethnos]', War 4.231; 'naturally of a most savage and murderous disposition', War 4.310) that fight against the priestly moderate faction 'introducing into every department perfect lawlessness' (War 7.267).

Josephus' vilification of the Idumaeans, however, did not extend to his treatment of the biblical traditions of Esau, a character that he treats under a surprisingly positive light. Feldman suggests that the equation of Edom with Rome made by the Jewish tradition already existed in Josephus' times: his relatively sympathetic treatment of Esau would express the dilemma of a Judaean of priestly family that inherited all sorts of prejudices against the Idumaeans but that, because of his loyalty to the Romans, could not denigrate Esau without diminishing respect for Rome (Feldman 1998: 314-24). This explanation is problematic, because it assumes Romans were well aware of the equation between Rome and Edom, which is not sure it was already established in the 1st century CE, and that there was Roman concern about what the recently defeated Jews thought about them. The portrait presented by Josephus continues in fact the long tradition of benign treatment of Esau and his descendants that was popular among many Judaeans, tradition that did not wane even in the wake of calamities such as Judah's fall. That Josephus was not alone in this stance is clear in the extensive and laudatory treatment that Pseudo-Philo's Biblical Antiquities - a Jewish retelling of the Hebrew Bible from Adam to Saul written in the 1st or 2nd centuries CE - makes of Edomiterelated biblical characters and in the special attention paid to the Idumaean geography (Zeron 1981). Characters with Edomite background that are otherwise mentioned in passing in the Bible are given special distinction, such as 
Caleb, who is given a more prominent role and a notable genealogy with Edomite connections ( $L A B$ 15.3), and especially his son Cenaz (Kenaz), here transfigured into Israel's first judge, mighty warrior and prophet ( $L A B$ 25-28).

Yet Josephus' and Pseudo-Philo's standpoint was not universally shared by the Hellenized Jews. For Philo of Alexandria, Jacob and Esau were symbols of good and evil, while his exegesis of the biblical stories served him to reach to allegorical lessons contrasting the opposing ways of life of those who follow a higher moral behaviour (personified by the Israelites) versus those who cling to earthly things (the Edomites) (Begg 2007; Feldman 1998: 314-24).

The Idumaean involvement in the first Jewish revolt was their last known exploit as a collective group, although the name Idumaea was still referred to as a geographical name by Ptolemy and Jerome. They probably shared the fate of their Judaeans fellows, defeat and exile, and some would have joined the nascent Christian faith (cf. Mark 3:8). Concomitant with their gradual vanishing from history, since the 2nd century $\mathrm{CE}$, Edom's role in the Jewish literature gradually began to change, becoming more allegorical (de Lange 1978: 255). For many generations to come, Edom would be synonymous to Rome, while the Babylonian captivity was considered equivalent to life under Roman subjugation. It is probable that this identification began as early as the period of the Herodian client-states, although the 1st century BCE texts traditionally cited for supporting an early date for this tradition are vague and their interpretation conjectural (Feldman 1998: 322-3).

But the equation of Edom with Rome fully emerged in the wake of the Bar Kokhba revolt in $135 \mathrm{CE}$, particularly with the school of Akiba (Hadas-Lebel 1984, 2006: 497-511). The rabbinic commentaries on the birth of Jacob and Esau assume as given the fraternity between Israel-Jacob and Esau-Rome (de Lange 1978: 269-71; Kunin 1999: 21-4; Stern 1994: 18-21). Thus, the prediction of the two nations in Rebekah's womb (Gen. 25:23) is interpreted as the presence of "two rulers of nations ... Hadrian of the Gentiles and Solomon of Israel' (GnR 63.7), open allusion to Emperor Hadrian, suppressor of the Bar Kokhba revolt. In the exegesis of the narrative of Jacob's deceitful obtainment of his father's blessing (Gen. 27:22), one 3rd century CE rabbi commented that Jacob's laments over what the 'hands of Esau' have done to him 'are the cries caused by Hadrian the cursed who massacred eighty thousand myriads at Bethar' (Bar Kokhba's last stronghold) (GnR 65.21; Y. Ta'an 4.8, 68d; cf. Git. 57b, having Vespasian instead of Hadrian). The rabbis also made use of the old tradition of the Edomite stab-in-the-back, now transferred to Titus' destruction of the temple of Jerusalem in $70 \mathrm{CE}$. An early text of the Babylonian Talmud, in referring to the same biblical verse, states that 'the hands are those of Esau, that is the kingdom of evil which has destroyed our Temple, burnt our Sanctuary and exiled us from our country' (Git. 57b).

The use of the Edom-Rome imagery in the early rabbinic writings is not restricted to historical parables, and it was widely utilized in other contexts. Some texts allude to the voracious imperial administration personified by Edom; 'the eyes of Edom are never satisfied' grumbles a 3rd century CE rabbi 
(Levi, Ecclesiastes Rabba 1.7.9; a motif that still resonates in the 9th century CE Pesikta Rabbati, 10.1). Yet it is in the eschatological literature where Edom is a recurrent character, echoing seemingly unfulfiled Jewish hopes for the future downfall of Rome. The violent dissociation of the Judaean people from their homeland and the improbable restoration of their political independence in the coming future fed purely eschatological expectations in the Jewish Diaspora, the core of which saw Edom playing an important role, now a symbol of Christian Rome and later Byzantium (see Spurling 2009).

The rise to power of the Catholic Church added another source of contention related to the imagery of Esau, as the early Christians prefigured themselves associated with Jacob (Rom. 9:10-3). Whether the rabbinical association with Jacob developed from internalizing the Christian position or not, ${ }^{5}$ it is clear that the association of Edom with Rome emerged prior to the Christianization of the Roman Empire as a response to the defeats of the Jewish revolts in Palestine and the political and religious suppression that followed. But with the progressive disassociation of the rabbinical image of Edom from the realities of Roman Idumaea, Jewish memories of Edom were no longer fed by feelings of national resentment, fading instead into eschatological utopianisms full of allegorical references.

\section{Conclusion}

The role of Edom in the ancient Jewish tradition constitutes a unique case in the study of collective memories in antiquity. Its longevity throughout several centuries, perseverance during different historical situations, and visibility all over diverse written sources set it apart from other ancient cultures of resentment. Other known comparable traditions, such as the enmity between Assyria and Babylon and Rome and Carthage, even if extending through centuries and engendering literatures of antagonism, represented chiefly the ideology of the ruling elites. Unlike the Jewish memories of Edom, cultures of resentment in Assyria, Babylon, and Rome emerged as part of the effort to build, expand and strengthen the state institutions - palace, temple, senate, or army - during times of military conflict, feelings hardly shared by the rest of the population. To be sure, the growth of anti-Edomite polemics during the Persian and Hellenistic periods were incited by the priestly class and, later, manipulated by pro-Hasmonean supporters, but there is little evidence to suggest they formed part of a state-sponsored policy against the Idumaeans. To the contrary, polemics against Edom continued and proliferated during and after the ruling of the Herodian dynasty.

An additional uniqueness of the Jewish tradition of Edom is its focus on a foreign, minority group in Cisjordan with no territorial state of its own. Movements and immigration of people were recurrent phenomena in the ancient Near Eastern societies, while prejudices against foreigners were common (Beckman 2013;Van Lerbergue and Schoors 1995), but the prolonged tradition 
of diatribes against Edom was completely atypical. Atypical was also the lack of attribution of shared physical or mental characteristics to the Edomites/Idumaeans. This concept, so common to Greeks and Romans alike (for a definition of 'racism' in antiquity, see Isaac 2004: 23) and of course characteristic of Western anti-Semitism for 2,000 years, was totally alien to the Jewish tradition. Accusations against Edom were motivated by national, social, political, cultic, and even tribal and family conflicts, not racial prejudices. Even Josephus' characterization of the Idumaeans as a reckless horde pointed more to their reproachful conduct during the Jewish revolt than to the mental capacities of the ethnos. In this sense, Jewish denigration of Edom was xenophobic, but not 'racist'.

Jewish polemics against other peoples, to be sure, were not limited to the Edomites. Philistines, Moabites, Ammonites, Samaritans, and others are well known to have been the target of biblical and non-biblical denunciations. However, most surviving Jewish polemics against other peoples were one-sided and historically-specific, nothing like the lengthy, varied mixture of traditions we have about Edom. The prominence of Edom in the Jewish literature transcended different periods, and its role was always related, at least until the first Jewish revolt against Rome, to the historical Edomites/Idumaeans living side by side with the Judaeans, unlike late Jewish characterization of other peoples totally disconnected from historical reality (e.g. Avioz 2015).

Behind the apparent homogeneity of the Jewish culture of resentment towards Edom lies a long history with several themes that emerged following the ups and downs of the Judaean struggle for self-determination:

1. Growth of a multicultural society in Judah's northern Negev and emergence of the 'brotherhood' of Jacob and Esau stories;

2. Destruction of the kingdom of Judah and appearance of scapegoat and 'stab-in-the-back' notions (Edom's guilt in the fall of Judah and destruction of the temple of Jerusalem);

3. Consolidation of a multicultural community in Idumaea and creation of fictive kinship relationships between Judaean and Edomite groups through eponymous ancestors;

4. Conflicts over cultic positions in Yehud Jerusalem and generation of fictive Edomite-related eponymous cultic personnel;

5. Hasmonean expansionism in Idumaea and conception of Edom as perpetual adversary;

6. Internal struggles during the first Jewish revolt and characterization of Edomites as savage mob;

7. Jewish anti-Roman struggles and depiction of Edom as Rome.

It is clear that the role of Edom in the Jewish literature was not altogether negative and in certain contexts was certainly positive. However, what transcended the different periods was the constant use and reuse of the figure of Edom in different circumstances and for different reasons. Edom could 
signify several things at the same time: emotions of brotherly affection for those defending policies of inclusion of foreigners into Israel's realm and sentiments of resentment resting on memories of humiliation or rationalizations of policies of external conquests. Some conceptualizations responded to, and took as point of departure, the historical realities of the contemporary Edomites/Idumaeans as they affected the Judaeans. The growth and consolidation of a multicultural society in the northern Negev and Idumaea and the posterior Hasmomean wars in the same area are a case in point. But in other cases, the role of Edom was far removed from specific historical situations; Jewish writers rarely missed an opportunity to associate Edom to the military catastrophes that fell upon the Judaeans. The Edomites' destruction of Jerusalem's first and second temples is outright fabrication. Few if any Edomite/Idumaean sources survive to check the historical validity of, and the corresponding responses to, these vilifications. What is clear is that these different conceptualizations, it does not matter if real or invented, were reshaped and twisted once and again, becoming central concepts of the several Jewish national identities that materialized in the Hellenistic period.

\section{Acknowledgements}

This article was written during my tenure as Research Fellow at the Department of Archaeology, University of Sydney, thanks to an Endeavour Research Fellowship provided by the Australian Government, Department of Education and Training.

\section{Endnotes}

1 While some trace its emergence to the last decades of the kingdom of Judah (Grosby 1993: 18, Grosby 1999: 358-61, Grosby 2002: 44-5), others date it to Second Temple times (Weeks 2002: 154-6; Goodblatt 1999, 2006) and more specifically to the Hasmonean (Mendels 1997) and Roman periods (Aberbach 2000, 2003: 31-44, 2008: 28-36; Aberbach and Aberbach 2000).

2 The lowland region of Faynan saw the emergence of a chiefdom polity during the 10th-9th centuries BCE (Tebes 2013: 40-2), but its relationship with the later Edomite polity is hotly debated. 3 The more neutral term late Iron Age Southern Transjordan-Negev Pottery (STNP) is to be preferred (Tebes 2011a).

4 According to Babylonian chronicles, king Nabonidus only subdued Edom in 551 BCE; Tebes 2013: 51 .

5 For literature, see Cohen 1967; Yuval 2006: 16; Lanfranchi and Verheyden 2013.

\section{References}

Aberbach, D. 2000. 'The Roman-Jewish wars and Hebrew cultural nationalism', Nations and Nationalism 6, 3: 347-362. 
Aberbach, D. 2003. Major Turning Points in Jewish Intellectual History. London: Palgrave Macmillan.

Aberbach, D. 2005. 'Nationalism and the Hebrew Bible', Nations and Nationalism 11, 2: $223-242$.

Aberbach, D. 2008. Jewish Cultural Nationalism: Origins and Influences. Oxford: Routledge.

Aberbach, M. and Aberbach, D. 2000. The Roman-Jewish Wars and Hebrew Cultural Nationalism. London: Palgrave Macmillan.

Amit, Y. 2003. 'Epoch and genre: The sixth century and the growth of hidden polemics' in O. Lipschits, J. Blenkinsopp (eds.), Judah and the Judaeans in the Neo-Babylonian Period. Eisenbrauns: Winona Lake: 135-151.

Amzallag, N. 2015. Esau in Jerusalem: The Rise of a Seirite Religious Elite in Zion in the Persian Period. Paris: Gabalda.

Appelbaum, A. 2009. 'The Idumaeans' in Josephus' the Jewish war', Journal for the Study of Judaism 40: 1-22.

Avioz, M. 2015. 'The Philistines in Josephus' writings', Theologische Zeitschrift 71: 144-155.

Barash, D. P. and Webel, C. P. 2013. Peace and Conflict Studies, 3rd edn. Los Angeles: SAGE.

Bartlett, J. R. 1989. Edom and the Edomites. Sheffield: Sheffield Academic Press.

Becking, B. 2016. 'The betrayal of Edom: Remarks on a claimed tradition', Theological Studies 72 , 4: $1-4$.

Beckman, G. 2013. 'Foreigners in the Ancient near East', Journal of the American Oriental Society 133, 2: 203-216.

Bedford, P. R. 2009. 'The Neo-Assyrian Empire' in I. Morris, W. Scheidel (eds.), Dynamics of Ancient Empires: State Power from Assyria to Byzantium. Oxford: Oxford University Press: 30-65.

Begg, C. 2007. 'Israel's confrontation with Edom (Num 20,14-21) according to Josephus and Philo', Revista Catalana de Teología 32, 1: 1-18.

Blenkinsopp, J. 2000. 'A case of benign imperial neglect and its consequences', Biblical Interpretation 8: 129-136.

Brinkman, J. A. 2006. 'Babylonia in the shadow of Assyria (747-626 B.C.)' in J. Boardman et al. (eds.), The Cambridge Ancient History. Second Edition. Vol. III, Part 2: The Assyrian and Babylonian Empires and other States of the Near East, from the Eighth to the Sixth Centuries B.C, Vol. 1991, 1st ed. Cambridge: Cambridge University Press: 1-69.

Bryan, D. J. 2002. 'The Herodians: A case of disputed identity. A review article of Nikos Kokkinos, The Herodian Dynasty', Tyndale Bulletin 53, 2: 223-238.

Chlup, J. T. 2012. 'Identity and the representation of war in Ancient Rome' in E. V. Baraban, S. Jaeger, A. Muller (eds.), Fighting Words and Images: Representing Wars across Disciplines. Toronto: University of Toronto Press: 209-232.

Coggings, R. J. and Knibb, M. A. 1979. The First and Second Books of Esdras. Cambridge: Cambridge University Press.

Cohen, E. E. 2000. The Athenian Nation. Princeton: Princeton University Press.

Cohen, G. 1967. 'Esau as symbol in early Medieval thought' in A. Altmann (ed.), Jewish Medieval and Renaissance Studies. Cambridge, Mass: Harvard University Press: 19-48.

Cohen, S. J. D. 1999. The Beginnings of Jewishness: Boundaries, Varieties, Uncertainties. Berkeley: University of California Press.

de Lange, N. R. M. 1978. 'Jewish attitudes to the Roman Empire' in P. D. A. Garnsey, C. R. Whittaker (eds.), Imperialism in the Ancient World. Cambridge: Syndics of the Cambridge University Press: 255-281.

Dicou, B. 1994. Edom, Israel's Brother and Antagonist: The Role of Edom in Biblical Prophecy and Story. Sheffield: Sheffield Academic Press.

Eckhardt, B. 2012. "'An Idumean, that is, a half-Jew'. Hasmoneans and Herodians between ancestry and merit" in B. Eckhardt (ed.), Jewish Identity and Politics between the Maccabees and Bar Kokhba Groups, Normativity, and Rituals. Brill: Leiden: 91-116.

Eph'al, I. 1982. The Ancient Arabs: Nomads on the Borders of the Fertile Crescent 9th-5th Centuries B. C. Leiden: Brill.

(C) The author(s) 2017. Nations and Nationalism (C) ASEN/John Wiley \& Sons Ltd 2017 
Erlich, A. and Kloner, A. 2008. Maresha Excavations Final Report II: Hellenistic Terracotta Figurines from the 1989-1996 Seasons. Jerusalem: Israel Antiquities Authority.

Eshel, E. and Kloner, A. 1996. 'An Aramaic ostracon of an Edomite marriage contract from Maresha dated 176 B.C.E', Israel Exploration Journal 46: 1-22.

Feldman, L.-H. 1998. Josephus's Interpretation of the Bible. Berkeley: University of California Press.

Frame, G. 2007, 1997. Babylonia 689-627 B.C. A Political History, 1st edn. Leiden: Nederlands Historisch-Archaeologisch Instituut te Istanbul.

Fried, L. 2007. 'From Xeno-Philia to -Phobia: Jewish encounters with the other' in Y. Levin (ed.), A Time of Change: Judah and Its Neighbors in the Persian and Early Hellenistic Period. London: Bloomsbury: 189-194.

Glazier-McDonald, B. 1995. 'Edom in the prophetical corpus' in D. V. Edelman (ed.), You Shall Not Abhor an Edomite for He is Your Brother. Edom and Seir in History and Tradition. Atlanta: Scholars Press: 23-32.

Goodblatt, D. 1999. 'Judean nationalism in the light of the Dead Sea scrolls' in D. Goodblatt, A. Pinnick, D. R. Schwartz (eds.), Historical Perspectives: From the Hasmoneans to Bar Kokhba in Light of the Dead Sea Scrolls, Proceedings of the Fourth International Symposium of the Orion Center, 27-31 January 1999. Brill: Leiden: 3-27.

Goodblatt, D. 2006. Elements of Ancient Jewish Nationalism. Cambridge: Cambridge University Press.

Graf, D. F. 2015. 'Arabs in Palestine from the Neo-Assyrian to the Persian Periods', ARAM 27, 1\&2: 283-299.

Grosby, S. 1993. 'Kinship, territory, and the nation in the historiography of ancient Israel', Zeitschrift für die Alttestamentliche Wissenschaft 105: 3-18.

Grosby, S. 1999. 'The chosen people of ancient Israel and the Occident: Why does nationality exist and survive?', Nations and Nationalism 5, 3: 357-380.

Grosby, S. 2002. Biblical Ideas of Nationality: Ancient and Modern. Winona Lake: Eisenbrauns.

Grosby, S. 2003. Nationalism: A Very Short Introduction. Oxford: Oxford University Press.

Gruen, E. S. 1992. Culture and National Identity in Republican Rome. Ithaca: Cornell University Press.

Gruen, E. S. 1998. Heritage and Hellenism: The Reinvention of Jewish Tradition. Berkeley: University of California Press.

Guillaume, P. 2013. 'The myth of the Edomite threat. Arad letters 24 and 40', KUSATU 15: 97-108.

Hadas-Lebel, M. 1984. 'Jacob et Esau ou Israel et Rome dans le Talmud et le Midrash', Revue de l'Histoire des Religions CCI 4: 369-392.

Hadas-Lebel, M. 2006. Jerusalem Against Rome. Leuven: Peeters.

Harkavy, R. E. 2000. 'Defeat, national humiliation, and the revenge motif in international politics', International Politics 37: 345-368.

Hobsbawm, E. 1996. The Age of Revolution 1789-1848, 1st ed.: 1962 edn. New York: Vintage Books.

Hornblower, S. and Spawforth, A. (eds.) 1998. The Oxford Companion to Classical Civilization. Oxford: Oxford University Press.

Hoyos, B. D. 1997. Unplanned Wars: The Origins of the First and Second Punic Wars. Berlin: de Gruyter.

Isaac, B. 2004. The Invention of Racism in Classical Antiquity. Princeton: Princeton University Press.

Kasher, A. 1988. Jews, Idumaeans and Ancient Arabs. Relations of the Jews in Eretz-Israel with Nationals of the Frontier and the Desert during the Hellenistic and Roman Era (332 B.C.E.-70 C.E.) Tübingen: Mohr.

Kessler, J. 2006. 'Persia's loyal Yahwists: Power identity and ethnicity in Achaemenid Yehud' in O. Lipschits, M. Oeming (eds.), Judah and the Judeans in the Persian Period. Eisenbrauns: Winona Lake: 91-122. 
Kloner, A. 2011. 'The identity of the Idumeans based on the archaeological evidence from Maresha' in O. Lipschits, G. N. Knoppers, M. Oeming (eds.), Judah and the Judeans in the Achaemenid Period: Negotiating Identity in an International Context. Eisenbrauns: Winona Lake: 563-573.

Kloner, A. 2015. 'Idumaean and the Idumaeans', ARAM 27, 1\&2: 177-185.

Knoppers, G. N. 2001. 'Intermarriage, social complexity, and ethnic diversity in the genealogy of Judah', Journal of Biblical Literature 120: 15-30.

Kohn, H. 1961. The Idea Of Nationalism: A Study in its Origins and Background, 1st ed.: 1944. New Brunswick: Transaction Publishers.

Kokkinos, N. 1998. The Herodian Dynasty: Origins, Role in Society and Eclipse. Sheffield: Sheffield Academic.

Kunin, S. D. 1999. 'Israel and the nations: A structuralist survey', Journal for the Study of the Old Testament 82: 19-43.

Lanfranchi, P. and Verheyden, J. 2013. 'Jacob and Esau: Who are they? The use of Romans 9:10-13 in anti-Jewish literature of the First Centuries' in T. Nicklas, A. Merkt, J. Verheyden (eds.), Ancient Perspectives on Paul. Göttingen: Vandenhoeck \& Ruprecht: 297-316.

Levin, Y. 2015. 'The formation of Idumean identity', ARAM 27, 1\&2: 187-202.

Limet, H. 2005. 'Ethnicity' in D. Snell (ed.), A Companion to the Ancient Near East. Oxford: Blackwell: 370-383.

Liverani, M. 1992. 'Nationality and political identity' in D. N. Freedman (ed.), Anchor Bible Dictionary, Vol. 4. New York: Doubleday: 1031-1037.

Machinist, P. 2006. 'Final response: On the study of the ancient language, writing and the state' in S. L. Sanders (ed.), Margins of Writing, Origins of Culture. Chicago: University of Chicago Press: 291-300.

Mann, M. 1986. The Sources of Social Power. Vol. I. A History of Power from the Beginning to. A. D. 1760. Cambridge: Cambridge University Press.

Marshak, A. K. 2012. 'Rise of the Idumeans: Ethnicity and politics in Herod's Judea' in B. Eckhardt (ed.), Jewish Identity and Politics between the Maccabees and Bar Kokhba Groups, Normativity, and Rituals. Brill: Leiden: 117-130.

Mendels, D. 1997. The Rise and Fall of Jewish Nationalism, 3rd ed. New York: Doubleday.

Motyl, A. (ed.) 2001. Encyclopedia of Nationalism. Vol. 2: Leaders, Movements, and Concepts. San Diego: Academic Press.

Na'aman, N. 2010. 'The Israelite-Judahite struggle for the patrimony of ancient Israel', Biblica 91, 1: $1-23$.

Parpola, S. 2004. 'National and ethnic identity in the Neo-Assyrian Empire and Assyrian Identity in post-Empire times', Journal of Assyrian Academic Studies 18, 2: 5-22.

Perry-Gal, L., Bar-Oz, G. and Erlich, A. 2015. 'Livestock animal trends in Idumaean Maresha: Preliminary analysis of cultural and economic aspects', ARAM 27, 1\&2: 213-226.

Pongratz-Leisten, B. 2001. 'The other and the enemy in the Mesopotamian conception of the world' in R. M. Whiting (ed.), Mythology and Mythologies. Methodological Approaches to Intercultural Influences. Helsinki: Neo-Assyrian Text Corpus Project: 195-231.

Porter, B. N. 1993. Images, Power, and Politics: Figurative Aspects of Esarhaddon's Babylonian Policy. Philadelphia: American Philosophical Society.

Radner, K. 2014. 'The Neo-Assyrian Empire' in M. Gehler, R. Rollinger (eds.), Imperien und Reiche in der Weltgeschichte. Epochenübergreifende und globalhistorische Vergleiche. Teil 1: Imperien des Altertums, Mittelalterliche und frühneuzeitliche Imperien. Wiesbaden: Harrasowitz: 101-119.

Ronen, I. 1988. 'Formation of Jewish nationalism among the Idumeans' in A. Kasher (ed.), Jews, Idumaeans and Ancient Arabs. Relations of the Jews in Eretz-Israel with Nationals of the Frontier and the Desert during the Hellenistic and Roman Era (332- B.C.E.-70 C.E.) Tübingen: Mohr: 214-221.

Roshwald, A. 2006. The Endurance of Nationalism: Ancient Roots and Modern Dilemmas. Cambridge: Cambridge University Press. 
Schivelbusch, W. 2003. The Culture of Defeat: On National Trauma, Mourning, and Recovery. New York: Metropolitan Books.

Schwartz, S. 2009. Imperialism and Jewish Society: 200 B.C.E. to 640 C.E. Princeton: Princeton University Press.

Sheriffs, D. C. T. 1988. 'A tale of two cities' - Nationalism in Zion and Babylon', Tyndale Bulletin 39: $19-57$.

Smith, A. D. 2002. The Ethnic Origins of Nations, 1st. ed.: 1986 edn. Oxford: Blackwell.

Smith, A. D. 2003. Chosen Peoples: Sacred Sources of National Identity. Oxford: Oxford University Press.

Snyder, L. L. 2003. The New Nationalism. New Brunswick: Transaction Publishers.

Spurling, H. 2009. 'The biblical symbol of Edom in Jewish eschatological and apocalyptic imagery' in J. P. Monferrer Sala, A. Urbán (eds.), Sacred Text: Explorations in Lexicography. Franfurt Au Main: Peter Lang: 271-299.

Stern, I. 2007. 'The population of Persian period Idumea according to the Ostraca: A study of ethnic boundaries and ethnogenesis' in Y. Levin (ed.), A Time of Change: Judah and Its Neighbors in the Persian and Early Hellenistic Period. London: Bloomsbury: 205-238.

Stern, I. 2012. 'Ethnic identities and circumcised Phalli at Hellenistic Maresha', Strata 30: 9-39.

Stern, I. and Noam, V. 2015. 'Holey vessels of Maresha', ARAM 27, 1\&2: 343-364.

Stern, S. 1994. Jewish Identity in Early Rabbinic Writings. Leiden: Brill.

Talshir, Z. 1999. I Esdras: From Origin to Translation. Atlanta: SBL.

Tebes, J. M. 2011a. 'The Potter's will: Spheres of production, distribution and consumption of the late Iron Age Southern Transjordan-Negev pottery', Strata 29: 61-101.

Tebes, J. M. 2011b. 'The Edomite involvement in the destruction of the first temple: A case of stabin-the-back tradition?' Journal for the Study of the Old Testament 36, 2: 219-255.

Tebes, J. M. 2013. Nómadas en la encrucijada: Sociedad, ideología y poder en los márgenes áridos del Levante meridional del primer milenio a.C. Oxford: Archaeopress.

Van Lerbergue, K. and Schoors, A. 1995. Immigration and Emigration within the Ancient Near East. Festschrift E. Lipiński. Peeters: Leuven.

VanderKam, J. C. 2001. The Book of Jubilees. Sheffield: Sheffield Academic Press.

Weeks, S. D. E. 2002. 'Biblical literature and the emergence of ancient Jewish nationalism', Biblical Interpretation 10, 2: 144-157.

Yuval, I. J. 2006. Two Nations in Your Womb: Perceptions of Jews and Christians in Late Antiquity and the Middle Ages. Berkeley: University of California Press.

Zeron, A. 1981. 'The Swansong of Edom', Journal of Jewish Studies 31: 190-198. 